\title{
The Samekulturen exhibition. A social actor at the Tromsø University Museum
}

\section{Knowledge production and shifting circumstances}

\author{
Trude Fonneland
}

\begin{abstract}
In 1973, the exhibition entitled Samekulturen (The Sámi Culture) opened its doors to the public for the first time, and for over forty years this exhibition has served as an important arena for the dissemination of Sámi culture to tourists, students and other visitors. Exhibitions have social and political consequences. Samekulturen as a social actor that contributes to the production of knowledge is the point of departure for this paper. In the view of the museological and ethno-political contexts in which Samekulturen was produced, the exhibition will be analysed as a historical document revealing how museological practices related to the representation of the Sámi have evolved over time.
\end{abstract}

Keywords: Knowledge production, Tromsø University Museum, Samekulturen, Ørnulv Vorren, social actor, material culture, shifting circumstances, heritage making.

Museums are not isolated entities, but must be approached as flexible organisations in which a whole range of relations and activities impact the valuation, collection and display of cultures and histories (Mason 2006:25). The production and the life of the Samekulturen (The Sámi Culture) exhibition provides a window into some of the networks that museums are entangled in, and how changing scientific paradigms and political ideologies influence museological practices.

The exhibition will be analysed with a view to the museological and ethno-political contexts in which it was produced. Referring to folklorist Barbara Kirshenblatt-Gimblett (1998), my premise is that Samekulturen does not only display, but acts in and influences, with greater or lesser success, the societal processes it is a part of. The exhibition, in other words, has social consequences - such as creating, maintaining and changing power relations, identities, categories and memories.

Produced by Professor Ørnulv Vorren, Samekulturen opened its doors to the public for the first time on 15 June 1973, and has been a permanent exhibition at Troms $\varnothing$ 
University Museum for over forty years. Samekulturen documents what Vorren saw as the last remains of traditional life forms among the Sámi in Norway and to some extent the exhibition reveals a common ambition among anthropologists, ethnographers and ethnologists in relation to cultural change and the spread of "civilization" (see Silvén 2016). Today, more than forty years after its opening the exhibition is still an important arena for the dissemination of Sámi culture to Tromsø University Museum's visitors.

The knowledge produced in museums is affected by constantly shifting circumstances, such as the impact from patrons, visitors, scientists and political and ideological discourses, and as the circumstances change over time, the science and the museums also change (see Penny 2002). These circumstances need to be considered as important documents that frame the conditions of production, circulation and interpretation of knowledge, and my aim in this paper is to track the changes that take place. What was unique about this exhibition, and in what ways was it innovative and modern? Who writes culture and under what historical and institutional constraints? These are all questions we can shed light on by examining more closely the specific conditions, questions and interests that intersected in the context of the design and development of the exhibition. Set against its historical backdrop, the politics of Samekulturen takes on new nuances, and addresses the value of Samekulturen as a historical document revealing how museological practice related to the representation of Sámi cultures has evolved over time.

In terms of methodology, this implies a close reading and analysis of Professor Ørnulv Vorren's archives at the Tromsø University Museum. Moreover, the museum's annual reports (Årsmeldinger) and documents produced by the scientific staff developing Samekulturen will be examined.

\section{The Tromsø University Museum}

As Glenn Penny argues, "the state of any museum actually represents the sum of its history" (2002:7). The idea to establish a museum in Troms $\varnothing$ was proposed publicly for the first time on July 19, 1846 by Instructor P. Schmidt in a column in Tromsø Stifstidende (Tromsø diocese paper). In 1870, a General Exhibition of Tromsø diocese (Almindelige Udstilling for Tromsø Stift) was organised according to the model of similar exhibitions that had been arranged in Norwegian cities further south (see Baglo 2019). With a particular focus on Sámi livelihoods, the exhibition collected and displayed 261 Sámi objects. Afterwards, several exhibitors gave their items to the committee so a permanent public collection could be established in Tromsø. The committee also invited other potential contributors to provide material for the collection. When Tromsø Museum was finally constituted on October 16,1872 , it was referred to as "a great step forward on the path of civilization" ("et stor Skridt fremad paa Civilisationens Bane") (see Thomsen and Storm 2002). This statement reflects an understanding of museums and exhibitions as important meeting places for the exchange of ideas and not least for public enlightenment (see Eriksen 2009).

Tromsø Museum is the oldest science institution in northern Norway and a precursor to the establishment of the University of Tromsø in 1968. Assigned responsibility for the northern part of the country and adjacent Arctic regions, the institution was formed during a time of racial tension and severe exploitation of northern resources. The political 
120 situation for minorities at the time was the policy of cultural assimilation of the Sámi and the Kvens.

The Sámi and Ethnographic Collection gained an important position at the museum already in its early days, and the dissemination of Sámi culture became an important feature of the institution. Thus, being represented in exhibitions at Tromsø Museum is part of what constitutes the history of the Sámi. In 1884, Professor Just K. Qvigstad (1853-1957) was appointed director of the "Lappian department" - a position he held until $1934 .{ }^{1}$ He was a non-Sámi academic educated in the fields of theology and philology, and with expertise in Sámi culture, history and language. In April 1947, on the award of the Qvigstad medal, ${ }^{2}$ Qvigstad gave a radical speech on the importance of strengthening Sámi research and argued that Tromsø Museum had to be the focal point for this type of study:

[...] with two thirds of the Lappish population within its borders, Norway has an international obligation to study their language, ethnography and culture. We need not be ashamed of what has already been done, but much still remains and if we are not to be outdistanced by our neighbours, the Swedes, we need more than a chair in Lappish and a chair in ethnography at the University of Oslo. One obvious step is for Tromsø Museum to appoint a person whose sole purview is Lappish research. And not least, research into what has up to now been ignored, namely the material culture of the Lapps. But we must hurry. Times are changing, and life is taking on other forms, also that of the Lapps. One more generation and it will be too late (translation in Hansen 1992:47).

In 1949, Qvigstad's appeal bore fruit and a Sámi ethnographic department was established where the non-Sámi ethnographer Ørnulv Vorren was appointed head of department, and the work to save "the material culture of the Lapps" soon became a main task of the department. Shortly after being hired Vorren started to apply for funding and to draw the outlines for a permanent exhibition of Sámi cultures.

\section{ØRNULV VORREN AND THE PRODUCTION OF SAMEKULTUREN}

In recent decades, the scholarly gaze has been increasingly turned from the Indigenous object to researchers who study the Indigenous and to the societal processes that have regulated the production of such knowledge in the past and the present (e.g. Tuck \& Yang 2012).

As head of department and person in charge of the production of Samekulturen, Ørnulv Vorren must be seen as an historical agent whose research on the Sámi has been materialised into the first permanent exhibition of Sámi cultures in the Norwegian part of Sápmi. By focusing on Vorren's background, interests and publications, and the specific political and ideological climates in which they were set, knowledge on the contexts of Sámi research and its dissemination at the Tromsø University Museum is revealed. Despite Vorren's influential role, his research and work on Sámi culture and history have to a limited extent been illuminated in a research context.

Vorren studied ethnography at the University of Oslo and graduated in the early 1940s. For cultural subjects such as ethnology and ethnography, the first decades of the twentieth century were a period of transition between different approaches that have been called "evolutionism" (the study of cultural development as a gradual process from simple to more complex forms of culture), "diffusionism" (the study of how different cultural elements spread geographically) and "acculturation" 
(the study of changes in a society as a result of the direct contact of one society with another). A look into Vorren's archives and publications reveals that he has clearly been influenced by the latter approach. He writes:

Cultural development is largely stimulated by influence and borrowing. We thus see striking and clear results of the contact between Sámi cultures and other cultures. This contact has been increasing, and it is particularly strong in our country. Nowadays, the contact with the Norwegian peasant and fishing culture is no longer so prevalent. Today, the modern western European civilization, the "machine culture", is also manifesting itself in Sámi areas (Ørnulv Vorren, Sámi Archives, box 90, folder 1345, my translation).

Vorren started his museum career at a time when both the Norwegian and Sámi societies were rapidly changing. This time period was influenced by the growing Sámi political movement, the building of the Norwegian welfare state and expanding modern scholarly research. Vorren did not oppose the modernisation of the life of the Sámi, but he still wanted to fulfil what Qvigstad had pointed out as a major responsibility of the department, namely, to document the material culture of the Sámi "before it was too late" (Vorren \& Manker 1957). As he argues: "One can be tempted to look at it as a sort of escape from Sámi culture into the machine culture. But one thing is certain, a strong cultural awareness is a necessary ballast in such a situation" (1972:110-111, my translation). The idea that Sámi culture was a vanishing entity was also perpetuated in the political activities (Evjen \& David 2015). The Norwegian state conducted a policy of forced assimilation, where the aim was to eradicate the Sámi culture. A prominent view was that to achieve economic growth in the Sámi areas "people had to get rid of, or cover up those social characteristics which Norwegians take as signs of Lappishness" (Eidheim 1971:56).

Inspired by Qvigstad's goal to study Sámi languages, ethnography and culture, Vorren drew up the overriding plan for research at the department with funds from the Norwegian Research Council. ${ }^{3}$ Tromsø Museum annually received funding from the Norwegian Research Council (NRC) to work on a priority list of themes. The council also financed two larger museum fact-finding missions so the head of department could look for impulses and inspiration abroad, and Vorren used this opportunity to visit museums in the United States and Canada. These visits, according to Vorren, had a major influence on the development of Samekulturen, and he was particularly inspired by new exhibition techniques as well as by the various museums' school services (Tromsø Museum Årsberetning 1967:74-75). Vorren points out:

The following museums were visited: Fields Museum, Chicago, Milwaukee Public Museum, Pitt Rivers Museum, Harvard University, Boston, the American Museum of Natural History, New York, the Smithsonian Institution, the National Museum of History and Technology and the National Museum of Washington D.C. In addition, I attended the Nome Museum, the anniversary exhibitions in Fairbanks and Anchorage, and the World Exposition in Montreal. These visits were extremely beneficial. [...] The material and experiences from the trip will hopefully soon be reflected in Tromsø Museum's exhibitions to the extent that they can be adapted (Tromsø Museum Årsberetning 1967:74-75, my translation).

Vorren had a rich network of contacts. One of the researchers who particularly inspired 


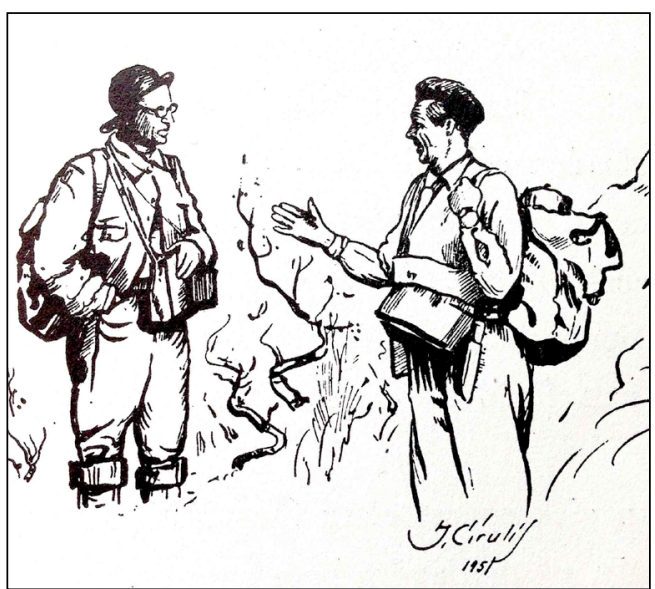

Fig. 1. Manker and Vorren during fieldwork in the Buolbmát (Polmak) area. A drawing by Janis Cirulis, published in Manker's book Över vidderna. Skisser och studier från landet i norr (1952:63).

and cooperated with Vorren was the Swedish ethnographer Ernst Manker (1893-1972). The pencil sketch shows Vorren and Manker taking part in joint field work in the area of Buolbmát (Polmak) in the county of Finnmark in 1951 - sharing knowledge and experiences. ${ }^{4}$ In 1957, Vorren and Manker published the book Samekulturen (Lapp Life and Customs, English edition 1962). ${ }^{5}$ In an interview with the curator Dikka Storm in 1993, Vorren points out that he saw a need for a popular scientific and concise representation of the Sámi due to an absence of knowledge about Sámi culture in society at large. He added: "The book Samekulturen sold like hotcakes. There was a need for that book. So many people came and asked all types of foolish questions really because they were so poorly informed. Therefore, I discovered that it was necessary to write such a book" (script 1, 1993, my translation). This book also became a precursor to and an important foundation for Vorren's work on the exhibition that bore the same name. Moreover, Manker's exhibition
Lapparna (The Lapps) that was on display at the Nordic Museum of Stockholm from 1947 until 1979 was an important model for Vorren in his work on Samekulturen. In particular, Lapparna's focus on the reindeer caravan and Manker's collaboration with Sámi people when working on setting up the exhibition are retained in Samekulturen.

\section{Producers or obJects OF RESEARCH?}

Samekulturen was financially supported by the Norwegian Arts Council so it was fitting that the director of the council, Ingeborg Lycke, opened the exhibition on 15 June 1973. The Norwegian Research Council had funded both the department's research plan that was one of the foundations of the exhibition and Vorren's museum fact-finding missions. By financing Samekulturen, government institutions participated in, supported and influenced the collecting of the "remains" of Sámi culture, making it clear that Sámi culture had a value - within the controlled frames of a Norwegian museum and research institution.

Through research, fieldwork, trips and publications based on priorities set in the research plan, Vorren collected artefacts and research material relevant for the planned exhibition, focusing particularly on the old hunting and trapping communities, reindeer nomadism, sea Sámi communities and Sámi pre-Christian religion and mythology (see Hovedplan for forskningsarbeidet ved Samisketnografisk avd, Action plan for research work at the Sami Ethnography Dept. at Tromsø Museum). The processes of selection, inclusion, exclusion and ordering are fundamental parts of museum work. As Anne Eriksen argues, the question relating to what kind of objects deserve to be part of a collection and an exhibition has been extremely relevant throughout the 
history of these institutions (2009:117). At the Tromsø Museum, the research plan was a clear governing document determining which objects were to be prioritised, and little by little, a systematic collection that satisfied the themes laid out by the plan was developed. ${ }^{6}$

In many ways Vorren can be considered a pioneer in Norway when it comes to involving indigenous people in the production of exhibitions. Until the Second World War, knowledge about the Sámi was produced largely by a small but highly influential group of Norwegian clergymen. The context was nation building and a general SocialDarwinist worldview. The emerging idea was of a people bound to vanish in the wake of modernisation and progress because of their racial characteristics and cultural inferiority. Scientific theories and lectures from the fields of ethnography and medicine contributed to this view.

The ideological climate after the Second World War represented a change in national minority policies, but not necessarily in scientific practice. While the idea of ethnic assimilation as a national strategy was no longer valid, some of the old scientific paradigms still existed within research. A more substantial change took place from the 1960 s onwards as new scientific paradigms and the general educational revolution swept through Western universities. These changes contributed to the opening of the University of Tromsø (1972), the Nordic Sámi Research Institute in Guovdageaidnu (1973) and the Sámi museum in Kárasjŏhka (1972) - all justified by referring to the "Sámi minority situation". On a discursive level, the changes led to consistent demands that research conducted upon the Sámi should be relevant, above all, to the Sámi themselves, and that the Sámi should be the producers or co-producers, rather than mere objects, of such knowledge (Lehtola 2005). Since the 1970s, aboriginality has been increasingly valorised as an integral part of the renovated postcolonial, multicultural national fabric, particularly for the purpose of international projection in tourism and cultural diplomacy. The Alta conflict is in this context an important political marker and a watershed in Sámi political history that caused Norway to change its official policy towards the Sámi. The "Alta affair" was triggered by the Norwegian Parliament's decision in November 1978 to approve a hydro-electric project that involved the damming of the Alta-Kautokeino River, which flows through central parts of Finnmark, Norway's northernmost county, and the heartland of the Sámi settlement. The Alta Affair that started as an environmental issue became an indigenous-people issue, and the ensuing protests and demonstrations brought the Sámi case to the world stage. In other words, the time of the opening of Samekulturen coincided with a political and cultural awakening unique in Sámi history.

As Tromsø Museum stood on the threshold of becoming a university museum, Vorren was eager to engage young Sámi academics. In the anniversary book, Museum og Universitet Tromsø Museum 1872-1972 (Museum and University, Tromsø Museum 1872-1972) Vorren reflects on the need to create exhibitions together with the Sámi minority, as well as the contemporary possibilities to achieve this goal due to the growing number of Sámi academics. He points out:

The longer one penetrates and differentiates the studies of culture and society, the more it becomes necessary to present material and problems "seen from within". At the time of the rise of the General Exhibition of Tromsø diocese in 1870, the possibilities for this were small, but today there are 


\section{Trude FonNeland}

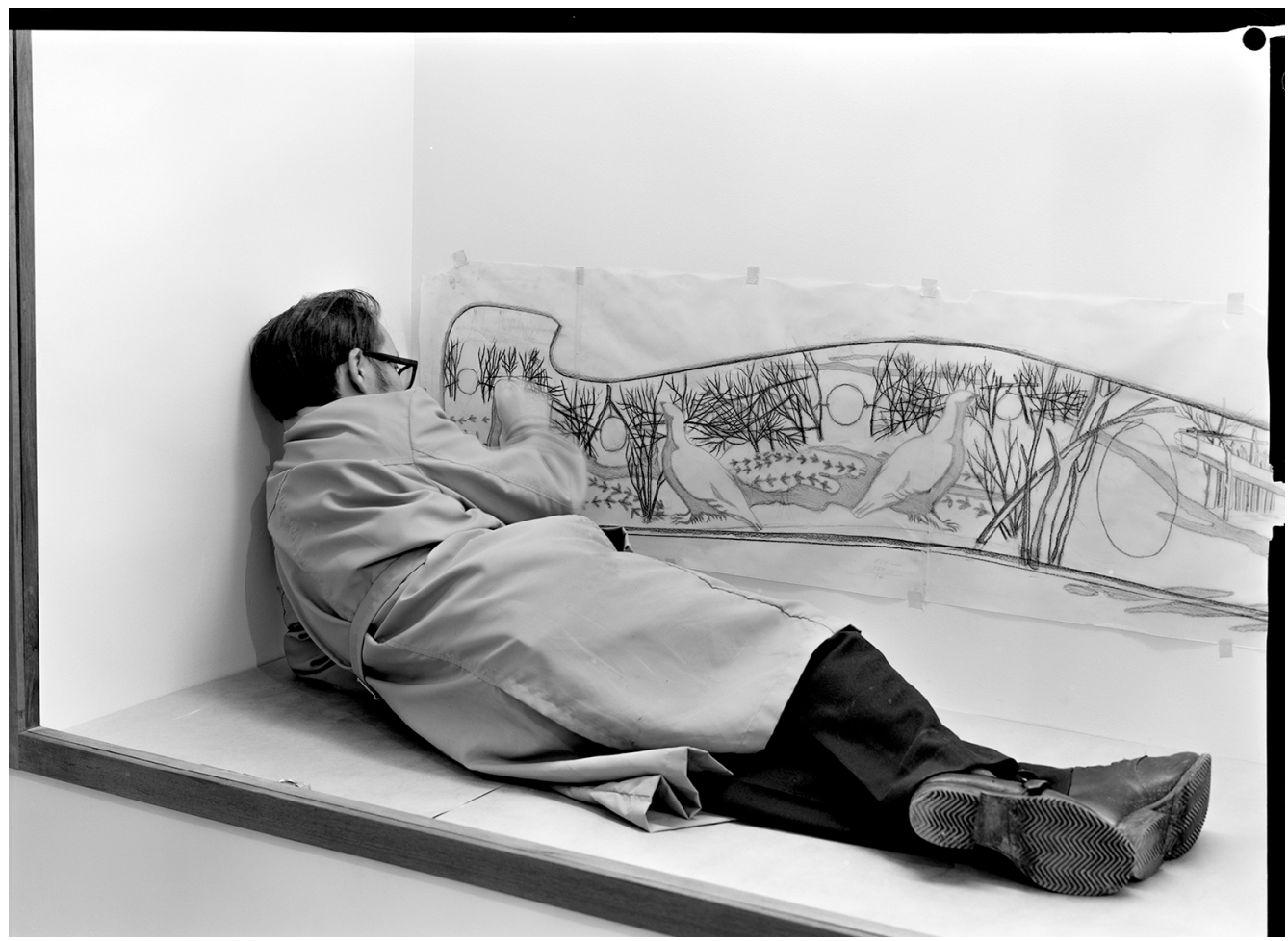

Fig. 2. The picture shows Iver Jåks concentrating on his work in one of Samekulturen's showcases illustrating the trapping of grous. Photo Olga Kvalheim, Photo Archive, the Tromsø University Museum, printed with permission.

great opportunities, as an ever-increasing number of Sámi academics are now turning to the social sciences (1972: 110-111, my translation).

From 1967 to 1972 the Sámi artist Iver Jåks (1932-2007), with his academic background from the National Crafts and Art Industry School and from the Copenhagen Academy of Fine Arts, received a scholarship from the Norwegian Arts Council to illustrate the exhibition. By studying the collected Sámi objects, Jåks acquired unique knowledge on how various objects like the náhppi (milk bowl) and the goavddis (drum) had been shaped for practical use, and this knowledge greatly inspired his later works (see Hanssen 2002:42). ${ }^{7}$ Together with the artist Idar Ingebrigtsen (1917-2004), Jåks was given the opportunity to put his personal touch on dioramas and showcases. ${ }^{8}$

In the early 1970s, the number of academic posts increased significantly, and several of the people hired for these positions had a Sámi background. The scientific staff at the museum consisted of, among others, Alf Isak Keskitalo, who later became the first director of Sámiid Vuorká-Dávvirat (The Sámi Collections in Kárasjŏhka), Johan Albert Kalstad, Mari 
Teigmo, Bjørn Aarseth and later President of the Sámidiggi in Norway, Ole Henrik Magga. ${ }^{9}$ The Sámi academics took part in collecting the materials, setting up the exhibition and organising the museum's school service.

Despite the Sámi academics' role in setting up Samekulturen, in a speech held at the Seventh Nordic Ethnographic Conference in Tromsø, Alf Isak Keskitalo points out a number of problems in Nordic "ethno-scientific" research on the Sámi. He argues, for example, that as objects of study, the Sámi have had no opportunities to establish symmetric and balanced relationships with the ethno-scientist studying them (1974/1994).

As Linda Tuhiwai Smith points out, the idea of excluding indigenous knowledge, language and methodology was inherited from the colonial museum structure and remains the main challenge in building truly equal relationships, collaborations and sustainable futures between the indigenous and nonindigenous communities (1999). It is still clear that the Sámi research assistants played a major role in the development of Samekulturen and that they were regarded as important resources, both due to their education and their knowledge of Sámi culture.

\section{“A PERMANENT EXHibition SHOULD BE LIKE A TEXTBOOK" 10}

Vorren's statement on exhibition design at the Sámi museum seminar held in Folkemuseet (Norwegian Folk Museum) at Bygdøy in 1987 reflects his experiences working on the Samekulturen exhibition. Comparing the book that Vorren and Manker published in 1957 with the exhibition, it is evident that the book as well as the research plan function as foundations for and extensions of the themes expressed through the dioramas, showcases

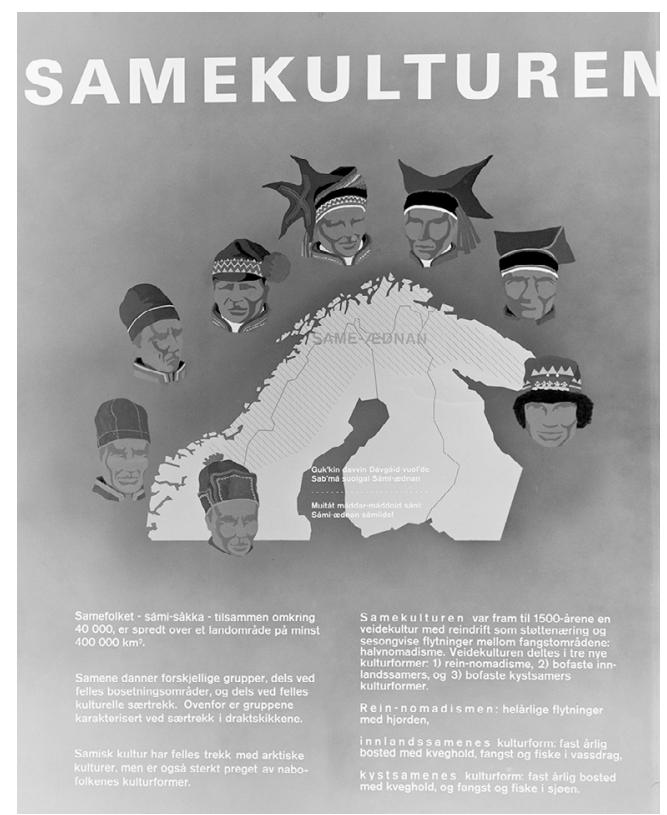

Fig. 3. Photo Olga Kvalheim, Photo Archive, the Tromsø University Museum, printed with permission.

and texts in Samekulturen. Sámi cultural life is presented strictly thematically, covering the subject as presented in the book's chapters with a focus on livelihood - particularly reindeer nomadism, which was widely regarded as the authentic Sámi lifestyle, as well as on handicraft and pre-Christian religion.

Just like the book's first chapter, the exhibition starts by mapping the Sámi territory to give a picture of the extent of the Sámi people's regions. Mapping is a political act. For Samekulturen, Iver Jåks developed a drawing of the land of the Sámi based on Vorren's and Manker's texts. ${ }^{11}$ In the book and exhibition the term used by Isak Saba, Sámi teacher and first Sámi member of the Norwegian Parliament, Same Ædnan, is highlighted as a symbol for the land of the Sámi. The map also shows that the 
126 term embraces a large area stretching from the White Sea in the northeast, to Lake Femund south of Røros, in Norway (Manker \& Vorren 1957:7). In a time characterised by harsh assimilation policies, this map makes a strong statement and highlights countercultural alternatives.

The exhibition's first showcases present sources of literature that draw attention to the Sámi presence in the north and display archaeological finds that testify to the fact that people lived in the northern areas as long as 8,000 years ago. In doing this, the exhibition, (as well as the book) challenges the theories on a Sámi migration route from Asia into Scandinavia that until recently had prevailed as a master narrative in several exhibitions on Sámi culture (see Spangen 2015). Schefferus, for instance, described the Sámi as newcomers to this part of Europe, originating somewhere in the east (see Schefferus, 1956[1673]:41). This was a concept that afforded the Swedish realm the possibility of claiming all the land and natural resources of Swedish and Finnish Sápmi. It also enforced the Swedish claim of sovereignty over all inhabitants of Sápmi.

Following an important theme in both the book and research plan, the next subject to be displayed is the Sámi's methods of utilising nature's resources through hunting and trapping. A variety of animal traps, spears, skis and a sewed boat, ${ }^{12}$ as well as illustrations of a bear and a wolf hunt, are displayed in the showcases at the exhibition's entrance.

The Skolt Sámi, sea Sámi and the inland Sámi are represented in separate showcases. But still, the traditions connected to reindeer nomadism are the ones that prevail in the exhibition. Illustrations of reindeer milking, pack reindeer, reindeer markers, lassos and packsaddles are found in several showcases. The reindeer and reindeer husbandry have become "the icons of Sámi culture and identity" (Silvén 2014:62). For Vorren, Sámi reindeer husbandry was a main area of research and a key subject of publications. Samekulturen's focus on the reindeer was also a way for Vorren to position himself as an acknowledged scholar. Even though the majority of the Sámi are not part of the reindeer husbandry culture, Samekulturen creates a strong link between Sámi identity and the reindeer. As Ivan Karp argues, exhibitions tell us who we are and, perhaps most significantly, who we are not (1991:15).

The largest diorama displays a wax mannequin on a sled dressed in a gákti (traditional costume) from Kárášjohka pulled by a reindeer in a caravan. ${ }^{13}$ The representation of the reindeer equipage was already widely spread through the works of Olaus Magnus, but through Schefferus' emblematic drawings in Lapponia (1673), the motif became of paramount importance for the general notions of Sáminess (see Mathisen 2001). Schefferus's drawing of the Sámi equipage is featured on the cover of Vorren's and Manker's book from 1957 and can be said to be highlighted as a symbol of the golden age of Sámi history. Artist Idar Ingebrigtsen has painted the diorama and his background illustrations of the snow-covered plain landscape, the lightning and the lines of reindeer reflect the spring migration. But, the diorama portrays an imaginative geography in Edward Said's sense (1985:101f), an exotified, constructed space used as a mirror of the conceited centre and for a gaze into the life of the last nomads of Europe. This gaze, one can argue, underpins a sensational image of and a distance to the ethnographic display.

In the article "Northern Borderlands and the Aesthetics of Ethnicity", Silje Opdahl Mathisen refers to the museological focus on reindeer husbandry as "Lapland's equipage". She argues 


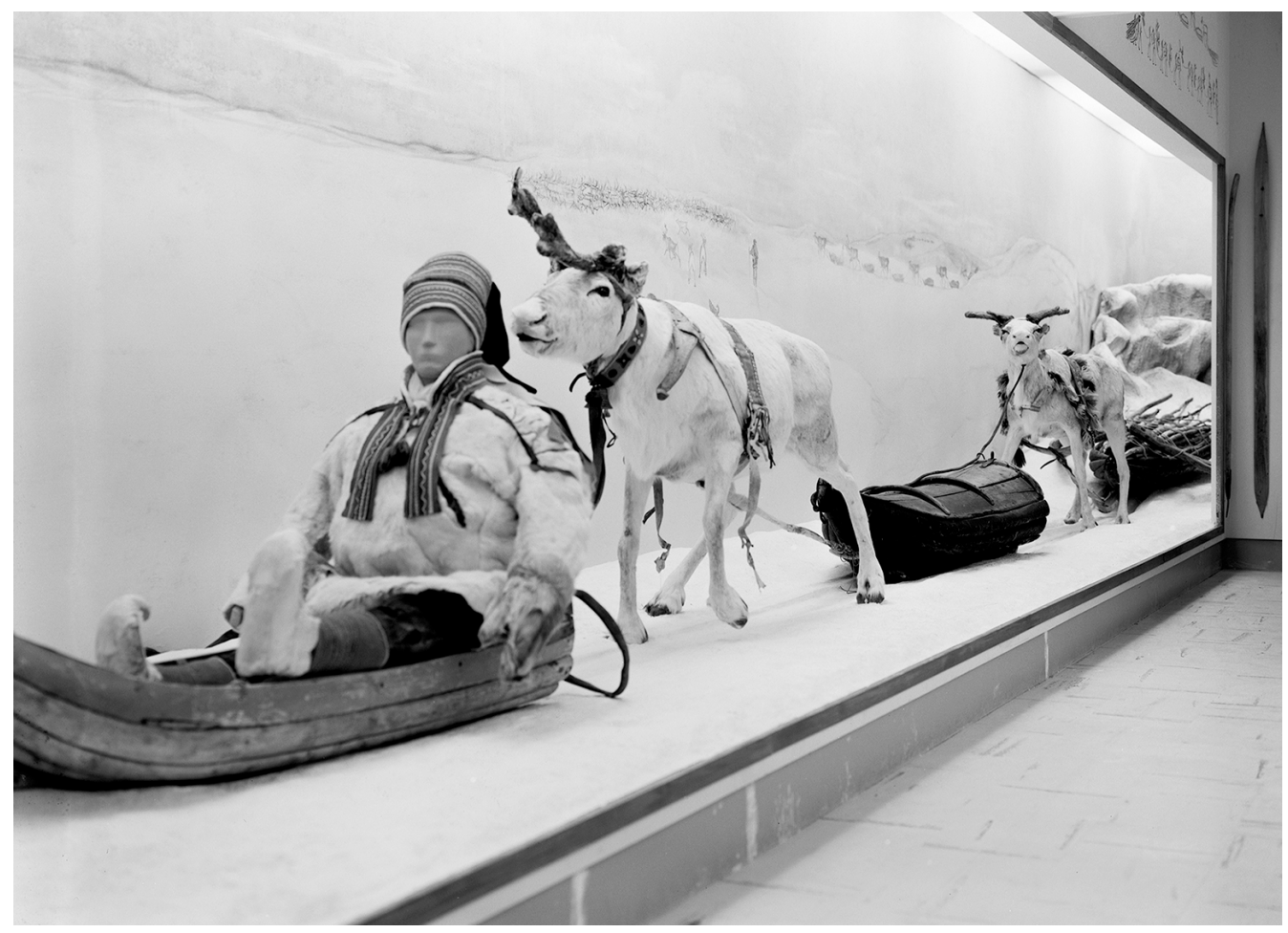

Fig. 4. Photo Olga Kvalheim, Photo Archive, the Tromsø University Museum, printed with permission.

that in museum contexts this type of portrayal of Sámi culture is more or less constant, and is found in the earliest ethnographic museums and in contemporary ethnographic and cultural-historical museums (2011). The diorama with the "Lapland equipage" can thus be seen as a constructed "myth of origin" that both simplifies the past and excludes contradictory voices.

(Fig. 5) The picture shows Vorren in one of the exhibition's showcases working on a mannequin, later to be replaced by a wax doll, illustrating the use of an instrument for scraping membrane and fibre from the skins. ${ }^{14}$ The picture also provides an impression of how many objects are presented in each showcase. About 900 items are displayed in the exhibition. The objects are set in context and arranged in typologies and series, but apart from the aesthetic guidelines, they are not set up as a story to be interpreted. The various series of items, such as the horn spoons, hats and giella (lasso rings), were and are part of various networks connecting different times and places. Thus in the exhibition they are "silenced". As Barbara Kirshenblatt-Gimblett points out: "In context approaches exert strong cognitive control over the objects, asserting the power of classification and arrangement to order large numbers of artifacts from diverse cultural and historical settings and to position them in relation to one another" (1991:390). 


\section{TRUde FonNeland}

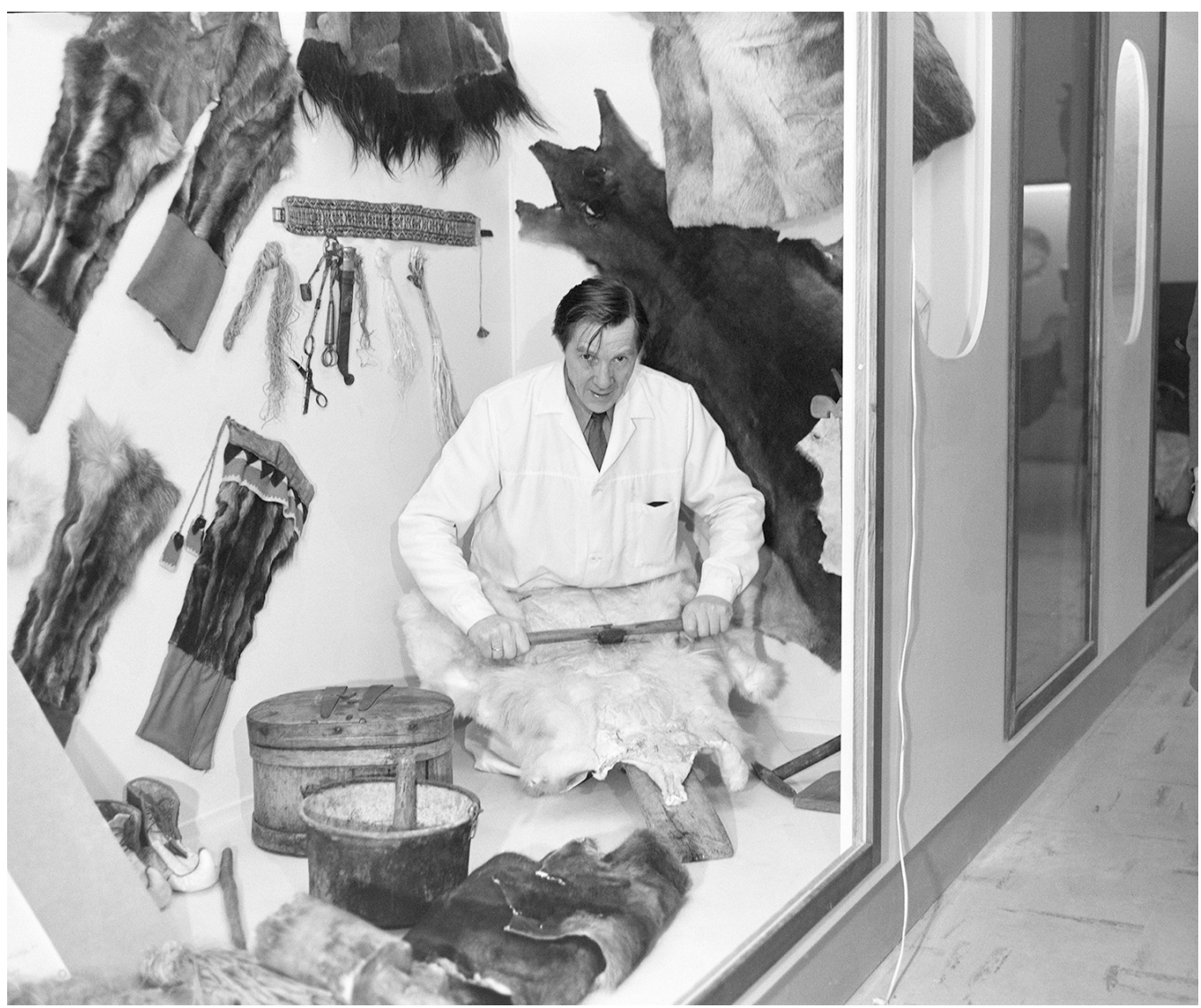

Fig. 5. Photo by Olga Kvalheim, Photo Archive, the Tromsø University Museum, printed with permission.

No texts describe where the items come from or who made and used them. They are instead included in an extensive narrative about a rich Sámi material culture comprising all Sámi cultures. The objects and accompanying illustrations inform about housing and Sámi building constructions, households and housework, activities related to the changing seasons, and not least about costume traditions. Overall, the many expressions of Sámi material culture provide knowledge on traditions that in the exhibition's opening year, according to Vorren, were in danger of being lost due to modernisation and a growing "machine culture", but in Samekulturen Vorren's aim is to allow visitors to be involved in the past due to the opportunity to be in direct contact with it $(1972,1957)$.

Nonetheless, when Sámi objects like the náphhi (milk bowl), the giella (lasso ring) and the goavddis (drum) are included in a museum context, the items and their meaning potential also change. Kirshenblatt-Gimblett precisely points out that an ethnographic object, "moves 
from curio to specimen to art" (1991:392). By incorporating the Sámi objects in various tableaus in Samekulturen Vorren thus retired the Sámi objects from service as utensils and paved the way for new approaches (see also Oskal 2014). When it comes to these types of translation processes that take place when developing the Samekulturen exhibition, it is important to bear in mind what James Clifford highlights in terms of the concept of translation: "Translation is not transmission [...] Cultural translation is always uneven, always betrayed. But this very interference and lack of smoothness is a source of new meanings, of historical traction" (2013:48-49).

In opening the exhibition, Sámi culture was showcased and legitimised as a "real" culture in the Norwegian public sphere. To many Sámi, this was a victory in itself, even though the showcases and dioramas can be said to be detached from time and space and highlight a minority of Sámi, namely those occupied with reindeer husbandry. As Ole Henrik Magga, the first President of the Sámediggi (the Sámi Parliament), points out in an interview published in the exhibition Sámi Stories: Art and Identity of an Arctic People, taking part in developing Samekulturen was the first time he had felt proud of his own culture. At the time of Samekulturen's opening in the early 1970s, the exhibition reached out with a message that for a long time had been under-communicated, namely that the Sámi culture has rich traditions worthy of care and protection for posterity.

\section{Changing museological practices}

Already in the 1970s, a post-colonial critique against the ethnographic museums' portrayal of indigenous people and non-Europeans gained momentum (see Simpson 2001). Gilane Tawadros, Director of the Institute of International Visual Arts (Iniva), pointed 129 out that: "The notion of Western culture as inherently progressive, sophisticated and above all superior [...]remains firmly imbedded in the cultural institutions of western Europe, not least in its museums" (1990:30-31). Debates on how to break away from unfavourable ethnographic practices and facilitate new curatorial traditions started to make an impact on Norwegian museum departments in the early 1990s. At the Tromsø University Museum, this led to discussions on the Samekulturen exhibition that in light of the critique increasingly was seen as a problematic representation of Sámi culture (see Kalsås 2011, 2015). Given the fact that Samekulturen presents Sámi culture as a reindeer culture with few references to other industries, we can argue that the thematic structure and the lack of reference to any specific points in time lead to an essentialist representation of the Sámi people. Distinct cultural symbols in this context, such as the reindeer, the lavvu and the gákti, appear as an unchangeable core of Sámi identity (see Mathisen 2001; Webb 2006; Eidheim, Bjørklund \& Brantenberg 2012).

In answer to this criticism, in the 1990s, parts of the showcases in Samekulturen were replaced by new ones focusing on Sámi political life. The intention was to produce a picture of the Sámi as actors who do not operate outside time and space, but who are actively participating in modern society. After a while, it was nevertheless decided to create a new exhibition, and in 2000 Sápmi - en nasjon blir til (Sápmi - Becoming a nation) was opened (see Ragazzi \& Nerici 2019). This exhibition focuses on how the Sámi in Norway experienced a political and cultural awakening during the post-war years. ${ }^{15}$ In the article "Negotiating with the Public - Ethnographic Museums and Ethnopolitics" (2012) some of 
130 the initiators and curators of the exhibition, Harald Eidheim, Ivar Bjørklund and Terje Brantenberg, point out that:

By making a presentation of a modern indigenous movement, we wanted to present an alternative to how most ethnographic museums have tended to represent the life of indigenous peoples, where cultural history and material objects tend to dominate displays and exhibitions (2012:96).

Since 2000, the two exhibitions Samekulturen and Sápmi - en nation blir til have co-existed, side by side, and have, in addition to their representations of Sámi culture and history, also shed light on museum historical practices. As Per Otnes argues:

[...] a text of today may become part of tomorrow's context - if it fares well in the field or fields that go into it; which implies it may serve to eradicate or at least phase out or modify older texts. Conversely, a text of today will enter the stage (or fields) against the background of previous received contexts, texts etc. already more or less consecrated by field agencies (2006:129-130).

In other words, the two exhibitions Samekulturen and Sápmi - en nasjon blir til are part of a rather intricate, intertextual interplay.

\section{SHIFTING CIRCUMSTANCES, CONTACT WORK AND IDENTITY FORMATIONS - CONCLUDING REMARKS}

An important issue is to consider if Samekulturen has a value beyond its role as a spotlight for museum historical practices. Due to the national assimilation policies, many Sámi have experienced a loss of language, cultural heritage and identity. In one of his many lectures Vorren points out that the museum's role is precisely to be an institution that must counter these effects and form a broad foundation that Sámi cultures can build on. ${ }^{16}$ Material culture plays an important role in the struggle for rights and identity formation. With the revitalization of Sámi cultures in the 1970s and 1980s, material cultural objects such as the gákti once more regained status within Sámi communities. One of the consequences of this was the desire to revitalize and reproduce traditional costumes based on the gákti that had been preserved in museum collections and exhibitions (see Finbog 2013:71). In a post in the newspaper Klassekampen on 3 November 2017, Sámi and PhD student Liisa Ravna Finborg argues:

The knowledge that we have left is important important to protect. Putting on the gákti is an act that contradicts the view of the Sámi culture as inferior. It is an act that challenges the shame of being Sámi that the assimilation policies created. To put on the gákti shows, as Sofia Jannok so strongly underlines, "We are still here" (Finbog in Klassekampen 3 November 2017, my translation).

Today, at the Tromsø University Museum, Samekulturen has become an important actor in these processes and every year a number of people visit the exhibition with an intention to revitalize the material objects that are found in the dioramas and showcases. Vorren's wish for the exhibition to form a foundation that Sámi cultures can build on is thus one step closer to reality. In terms of Samekulturen, it was foremost when the Sámi ethno-political arguments and struggle for equal rights gained ground, and when Tromsø Museum opened for a focus on these issues through the exhibition Sápmi - en nasjon blir til, that Samekulturen acquired Sámi relevance as a reciprocal arena of ongoing exchanges, renewal and articulations of "traditional futures" (Clifford 2013). The co- 
existence of the two exhibitions opens for new insights on Sámi identities and the production of knowledge and heritage. In this context, Samekulturen has a value beyond its role as a spotlight for museum historical practices, and has become a potential space where meetings between Sámi materiality and the visitor can take place. These meetings also open for new insights and for the creation of more ambitious and ambivalent ideas about identities, and thus generate interesting regimes of knowledge production and heritage making.

\section{Notes}

1. The other directors of the department before Vorren were Kristian Nissen (1934-36), Guttorm Gjessing (1936-40) and Th. Sjøvold (1946-49).

2. On Qvistad's 90-year anniversary in 1943, the Tromsø University Museum decided to make a gold medal which was to be awarded every fifth year to national or international researchers who had distinguished themselves within the field of Sámi research. In 1947, the medal was awarded to Prof. Konrad Nielsen.

3. Primarily, the plan consisted of six main themes: 1. The old hunting and trapping communities, 2. Reindeer nomadism, 3. Sea Sámi communities, 4. Social conditions among the Sámi today, 5 . The so-called "Marke-bygder", and 6. Sámi preChristian religion and mythology.

4. Fig. 1 shows Manker and Vorren during fieldwork in the Buolbmát (Polmak) area. A drawing by Janis Cirulis, published in Manker's book Över vidderna. Skisser och studier från landet i norr (1952:63).

5. This book was published in several languages, including English, German and Hungarian, and re-printed in a slightly revised edition in 1972.

6. In conjunction with Riksmessen (National Exhibition) in 1952, the Sámi ethnographic department was given the opportunity to set up a small exhibition on Sámi culture in the museum's vestibule and hall. According to Vorren, this was the first attempt at "a methodically constructed exhibition", and this exhibition was a precursor to the permanent exhibition on Sámi culture that opened in 1972 (Vorren 1972:111).

7. The Sámi collection at Tromsø Museum houses several sketches of Sámi objects by Iver Jåks from the period when he worked as the illustrator at Samekulturen.

8. The picture (Fig. 2) shows Iver Jåks in concentrated work in one of Samekulturen's showcases illustrating the trapping of grouse. Photo Olga Kvalheim, Photo Archive, the Tromsø University Museum, printed with permission.

9. Magga was hired as museum lecturer in 1973. He developed a teaching programme and a teaching booklet based on the exhibition for students from years four to nine in primary and lower secondary school entitled Samekulturen: Undervisningsopplegg for 4-.9. klasse (The Sami Culture: Teaching programme for years four to nine) (Magga 1973).

10. This was expressed by Ørnulv Vorren at the Sámi Museum Seminar in 1987 (Pareli 1994:353).

11. Photo Olga Kvalheim, Photo Archive, the Tromsø University Museum, printed with permission.

12. The technique of sewing boats was used for the construction of river and lake boats until the twentieth century. In 2017, the sewed river boat, which had been part of the exhibition from the opening, was given to the Skolt Sami museum in Neiden that opened in June 2017.

13. Photo Olga Kvalheim, Photo Archive, the Tromsø University Museum, printed with permission.

14. Photo by Olga Kvalheim, Photo Archive, the Tromsø University Museum, printed with permission.

15. See: Ragazzi \& Nerici 2019, in the current issue of Nordisk Museologi.

16. Sámi Archive/ Ørnulv Vorren, box 90, folder 1345, lecture: Samenes kulturutvikling og deres 
132 kulturelle og sosiale status i vårt samfunn (The Samis' cultural development and their cultural and social status within our society).

\section{REFERENCES}

\section{Interviews}

Dikka Storm - interview with Ørnulv Vorren 1993. (Sámi Archives, Tromsø University Museum).

Ole Henrik Magga, 2014. Video-interview by Marit A. Hauan and Rossella Ragazzi. Exhibition "Sámi Stories Art and Identity of an Arctic People".

\section{Literature}

Baglo, Cathrine 2019. "The disappearance of the Sea Sámi as a cultural display category”. Nordic Museology 3, 25-44.

Clifford, James 2013. Returns: Becoming Indigenous in the Twenty-First Century. Cambridge: Harvard University Press.

Eidheim, Harald 1971. Aspects of the Lappish Minority Situation. Oslo: Universitetsforlaget.

Eidheim, Harald, Bjørklund, Ivar \& Terje Brantenberg 2012. "Negotiating with the public - Ethnographic museums and ethnopolitics." Museum \& Society 10:2, 95-120.

Eriksen, Anne 2009. Museum. En kulturhistorie. Oslo: Pax Forlag.

Evjen, Bjørg \& David R. M. Beck 2015. “Growing indigenous influence on research, extended perspectives, and a new methodology: A historical approach". In Kathryn W. Shanley, Bjørg Evjen, \& S. James Anaya (eds.). Mapping Indigenous Presence: North Scandinavian and North American Perspectives. Tucson: Arizona University Press, 27-56.

Finbog, Liisa Rávna 2013. Med nav og eiker. Hvordan markesámisk identitet skapes, reforhandles, vedlikeholdes og utvikler seg ved Várdobáiki sámisk senter. Master's degree thesis in museology:

University of Oslo.

Finbog, Liisa Rávna 2017. Klassekampen 3/11/2017.
Hansen, Lars Ivar 1992. "Just K. Qvigstad's contribution to the study of Sámi culture." Acta Borealia 9:2, 4768, DOI: $10.1080 / 08003839208580416$.

Hanssen, Caroline Serck 2002. "Iver Jåk’s kunsternskap - et riss." In Bjarne Eilertsen, Dikka Storm, Hege Olaussen, Nils Jernsletten \& Sigmund Nesset (eds.). Ofelas. Iver Jåks Veiviseren. Universitetsbiblioteket i Tromsøs skriftserie: Ravnetrykk, 39-51.

Kalsås, Vidar Fagerheim 2011. Minoritetar på utstilling: Framstillinga av samane og romanifolket sin historie på museumsutstillingar. Master's degree thesis, University of Bergen.

Kalsås, Vidar Fagerheim 2015. "Minority history in museums. Between ethnopolitics and museology." Nordisk Museologi 2, 33-48.

Karp, Ivan 1991. "Culture and representation." In Ivan Karp \& Steven D. Lavine, (eds.). Exhibiting Cultures: the Poetics and Politics of Museum Display. Washington and London: Smithsonian Institution Press, 11-32.

Kirshenblatt-Gimblett, Barbro 1998. Destination Culture: Tourism, Museums, and Heritage. California: University of California Press.

Manker, Ernst 1952. Över vidderna. Skisser och studier från landet $i$ norr. Stockholm: LT.

Mason, Rhiannon 2006. "Culture theory and museum studies." In Sharon MacDonald (ed.). A Companion to Museum Studies. Oxford: Blackwell, 17-31.

Mathisen, Silje Opdahl 2014. "Northern borderlands and the aesthetics of ethnicity. Intervisuality and the representations of the Sami in early exhibitions at national cultural museums in Norway and Sweden." Arv 67, 57-72.

Mathisen, Stein R. 2001. "Den naturlige samen: Narrative konstruksjoner av 'de andre' i norsk tradisjon." In Line Alice Ytrehus (ed.). Fortellinger om "den andre". Kristiansand: Høyskoleforlaget, 84-98.

Oskal, Nils 2014. "The character of the milk bowl as a separate world, and the world as a multitudinous 


\section{The Samekulturen EXhibition. A SOCIAL ACtOR AT The Tromsø University Museum}

totality of references." In Marit Anne Hauan (ed.). Sami Stories. Stamsund: Orkana Akademisk, 79-89.

Otnes, Per. 2006. "Retrospect on 'The Sami Nation'. Text, context, field, symbolic violence. Confessions of a bordering actor." In Vigdis Stordahl (ed.). Samisk identitet, kontinuitet og endring. Dieđut, Guovdageaidnu: Sámi instituhtta, 127-155.

Pareli, Leif 1994. "Samisk utstilling ved Norsk Folkemuseum." In Dikka Storm, Nils Jernsletten, Nils Aarseth \& Per Kyrre Reymert (eds.). Festskrift til Ørnulv Vorren. Tromsø: Tromsø Museum, Universitetet i Tromsø, 353-371.

Penny, H. Glenn 2002. Objects of Culture: Ethnology and Ethnographic Museums in Imperial Germany. Chapel Hill: The University of North Carolina Press.

Ragazzi, Rossella \& Giacomo Nerici 2019.

"Discourses, practices and performances in Sámi museology at Tromsø University Museum." Nordisk Museologi 3, 134-151.

Said, Edward W. 1985. Orientalism. London: Penguin Books.

Silvén, Eva, 2016. "Hemfört, bortfört, återfört. Museerna och det samiska kulturarvet." In Johan Hegardt \& Trond Lundemo (eds.). Historiens hemvist. III. Minne, medier och materialitet I. Göteborg and Stockholm: Makadam Förlag, 189-217.

Silvén, Eva, 2014. "Constructiong a Sami cultural heritage: Essentialism and emancipation." Ethnologia Scandinavica: A Journal for Nordic Ethnology 44, 59-74.

Simpson, Moira 2001. Making Representations: Museums in the Post-colonial Era. New York and London: Routledge.

Smith, Linda Tuhiwai 1999. Decolonizing Methodologies. Research and Indigenous Peoples. London: Otago University Press Zed Books.
Spangen, Marte 2015. "Without a trace? The Sámi in the Swedish History Museum." Nordisk Museologi $2,17-32$.

Tawadros, Gilliane 1990. "Is the past a foreign country?" Museum Journal 90, 30-41.

Thomsen, Elsebeth \& Dikka Storm 2002. "Det mangfoldige museum: samlingene ved Tromsø Museum Universitetsmuseet." Ottar, Popularvitenskapelig tidsskrift fra Tromsø museum Universitetsmuseet. Tromsø: Tromsø Museum, Universitetet i Tromsø, 3-12.

Tromsø Museums Årsberetning 1967, Universitetsforlaget: Tromsø, Oslo.

Tuck, Eve \& K. Wayne Yang 2012. "Decolonization is not a metaphor." Decolonization: Indigeneity, Education and Society 1:1, 1-40.

Vorren, Ørnulv 1972. Museum og Universitet. Jubileumsskrift til Tromsø Museum 1872-1972. Tromsø - Oslo - Bergen: Universitetsforlaget.

Vorren, Ørnulv \& Ernst Manker 1957. Samekulturen. En oversikt. Tromsø Museum: Tromsø.

Webb, Sharon 2006. "Making museums, making people. Three representation of the Sámi through material culture." Public Archaeology 5:3, 167-183.

Witcomb, Andrea 2003. Re-imagining the Museum: Beyond the Mausoleum. London \& New York: Routledge.

Trude Fonneland, Professor

trude.fonneland@uit.no

Norges arktiske universitetsmuseum og akademi for kunstfag

UiT Norges arktiske universitet

Postboks 6050 Langnes

9037 Tromsø, Norway 